\title{
For the Market, or 'For Our Friends'? The Politics of Banking Sector Legal Reform in the Post-Communist Region after 1989
}

Citation for published version (APA):

Spendzharova, A. (2008). For the Market, or 'For Our Friends'? The Politics of Banking Sector Legal Reform in the Post-Communist Region after 1989. Comparative European Politics, 6(4), 432-462. https://doi.org/10.1057/cep.2008.1

Document status and date:

Published: 01/01/2008

DOI:

10.1057/cep.2008.1

Document Version:

Publisher's PDF, also known as Version of record

\section{Document license:}

Taverne

Please check the document version of this publication:

- A submitted manuscript is the version of the article upon submission and before peer-review. There can be important differences between the submitted version and the official published version of record.

People interested in the research are advised to contact the author for the final version of the publication, or visit the DOI to the publisher's website.

- The final author version and the galley proof are versions of the publication after peer review.

- The final published version features the final layout of the paper including the volume, issue and page numbers.

Link to publication

\footnotetext{
General rights rights.

- You may freely distribute the URL identifying the publication in the public portal. please follow below link for the End User Agreement:

www.umlib.nl/taverne-license

Take down policy

If you believe that this document breaches copyright please contact us at:

repository@maastrichtuniversity.nl

providing details and we will investigate your claim.
}

Copyright and moral rights for the publications made accessible in the public portal are retained by the authors and/or other copyright owners and it is a condition of accessing publications that users recognise and abide by the legal requirements associated with these

- Users may download and print one copy of any publication from the public portal for the purpose of private study or research.

- You may not further distribute the material or use it for any profit-making activity or commercial gain

If the publication is distributed under the terms of Article $25 \mathrm{fa}$ of the Dutch Copyright Act, indicated by the "Taverne" license above, 


\title{
For the Market or 'For Our Friends'? The Politics of Banking Sector Legal Reform in the Post-Communist Region After 1989
}

\begin{abstract}
Aneta B. Spendzharova
Department of Political Science, Institute for Advanced Studies (IHS), Stumpergasse 56, Vienna A-1060, Austria.

E-mail: aneta@email.unc.edu

This article analyzes the political processes that have shaped legal reform of the banking sector in the post-communist region. The article identifies two patterns of reform and examines Hungary and Bulgaria as examples of each pattern. The strategy for changing banking sector legislation and its implementation in Hungary has been 'reforming for the market,' whereas the prevailing strategy in Bulgaria until 1997 was 'reforming for our friends.' After 1997, Bulgarian governments switched to 'reforming for the market.' I argue that this shift took place because of an important partisan change of the governing elites that reinforced the role of international actors and altered the elites' relationship with important domestic stakeholders. The article shows that front-runners of banking reform in the region such as Hungary introduced significant private ownership in the sector and, at the same time, the governing elites enhanced the state's regulatory capacity. By contrast, 'partial reform' regimes such as Bulgaria until 1997 undertook limited and selective ownership change and the governing elites weakened the state's regulatory capacity, thus giving a boost to the already existing clientelism.

Comparative European Politics (2008) 6, 432-462. doi:10.1057/cep.2008.1
\end{abstract}

Keywords: banking sector reform; regulatory politics; international actors; clientelism; Bulgaria; Hungary

\section{Introduction}

We have gained important insights about the pitfalls and successes of economic reform in the post-communist region since 1989. In the very beginning of transition, scholars explored the influence and policy impact of liberal economic ideas. According to Adam Przeworski (1991, 136) and Irena Grosfeld (1991, 147), economic experts in front-runner countries recognized the overriding importance of the market to achieve productive and allocative efficiency. Ellen Comisso $(1991,172)$ has emphasized the crucial role of the state in setting up a system of property rights and bolstering an independent 
judiciary that can adjudicate economic disputes. Furthermore, Peter Evans (1992, 141) has underscored the significance of state capacity not only in the sense of competent civil servants but also in the sense of a dense institutional structure that can regulate the economy.

This article examines an issue that has received less attention in the postcommunist transition literature - reform of the banking sector legal framework. ${ }^{1}$ Following the collapse of the Soviet bloc in the early 1990s, policy-makers in the region confronted daunting tasks. The orthodox principles of running a socialist planned economy no longer applied. Governments faced the challenge of laying the foundations of a market economy: Which economic reforms should be implemented and in what order? One fundamental challenge was to reduce the involvement of the state in the economy and, consequently, amend and update the legal framework to bring regulations in line with the new economic conditions. Legal reform of the banking sector is a crucial component of economic liberalization and reveals the difficulties of building market institutions.

The banking sector is the main channel of financial intermediation in the region. Scholars of political economy have examined the differences between 'bank-based' and 'market-based' financial systems. In 'bank-based' systems such as Germany banks are the main source of capital, whereas in 'marketbased' systems such as the US firms raise capital predominantly via the stock and capital markets (Zysman, 1983; Levine, 2002). Occasionally, big companies from post-communist states have used the domestic and international stock markets to raise capital. However, banks remain the primary financial intermediaries in the area (Filer et al., 2001). Emerging small private businesses in sectors such as retail and textiles as well as restructuring stateowned conglomerates in sectors such as chemicals and metallurgy need capital to buy new equipment, renovate the production infrastructure, and invest in research and development. Hence, efficient and reliable banking services are indispensable for the emerging economies in the region.

Some 19 years after the beginning of transition, we can identify two distinct patterns of banking sector reform in the post-communist area. One I call 'reforming for the market', the other one 'reforming for our friends.' Hungary and Bulgaria are exemplary cases of those two patterns, respectively. The Hungarian case is analogous to other front-runners of economic reform such as the Czech Republic, Poland, and Estonia with respect to the emergence of a pro-market consensus early in transition (Comisso, 1991; Grosfeld, 1991; Bartlett, 1997). Even though the timing and method of reform in areas such as bank privatization differed somewhat across those cases, an in-depth investigation of the Hungarian path of banking sector legal reform reveals political decisions and laws that were significant for all front-runners. For its part, the Bulgarian case is typical of a broader range of post-communist cases 
such as Romania and Albania that have experienced the pronounced resistance of key political actors to transparency in banking and the absence of a consistent vision for transforming the financial sector. A careful analysis of the two representative cases - Hungary and Bulgaria - yields findings about the political processes shaping the banking sector legal framework that are generalizable to the post-communist region.

The post-communist transition has generated incentives for governing elites to pursue good quality legal reforms of the banking sector, but also incentives to stall such reforms. Introducing market logic in the operation of the banking sector can be beneficial, especially when a country transitions from a regime where the government alone determined capital allocation. The advantage of a reformed banking sector with clear rules of the game is that economic actors can engage in meaningful long-term planning and assume availability of capital and prompt financial services (Ditlbacher et al., 2002; Djarova, 2004). Therefore, political actors have certain incentives to seek good quality banking legal reforms in order to promote economic development and growth. Yet the banking sector also provides fertile ground for political interference and corruption, because influential political figures can provide access to preferential financing, and the state budget can be used to write off the bad loans in the portfolios of the state-owned banks. In the post-communist region, state-owned capital and assets have been often misused for the private benefits of influential political and economic elites (Hellman, 1998; Ganev, 2001a; Barnes, 2003; Gould, 2003; Hoff and Stiglitz, 2004). Juliet Johnson (2000) has shown how heightened political uncertainty, a half-hearted democratization process, and failure to uphold the rule of law facilitate the development and perpetuation of distorted incentives in the banking sphere.

There are legal remedies that can help prevent the misuse of the banks such as laws that promote transparency in bank operations and information-sharing concerning large loans; laws that allow the central bank to operate independently of short-term political pressures to bail out the government; and institutional mechanisms to monitor the compliance of the banks with the legal rules. The puzzles that animate this article are: How do governments decide whether to reform the country's banking sector legal framework and which course of legal change to pursue? Which mobilized actors, both domestic and international, influence legal change in the banking sector? To tackle these puzzles, I examine how the interaction of three factors - the partisan coloration of governing elites, the strength and type of mobilized domestic stakeholders, and the involvement of international actors - has shaped the quality of banking sector legal reform. The following section presents a theoretical framework to analyze the influence of political factors on banking sector reform and outlines the main theoretical arguments on which my research draws. ${ }^{2}$ After that, I investigate the causal mechanisms at work in my 
cases - Hungary and Bulgaria - exemplifying 'reforming for the market' and 'reforming for our friends,' respectively.

Since 1989, the consistent government strategy for changing banking sector legislation in Hungary has been 'reforming for the market.' While opportunism has occurred in the course of Hungarian banking reforms, the main political and economic actors have been strongly committed to economic liberalization. In general, this strategy brings medium- and long-term rewards in terms of attracting Western investors and setting up clear rules of the game in the banking sector. By stark contrast, the prevailing strategy for changing banking legislation used by most Bulgarian governments until 1997 was 'reforming for our friends.' Bulgarian law-makers did pass new banking laws that introduced some market principles in the operation of the banks. However, the existence of significant loopholes in those laws allowed key political actors to extract financial gains for themselves and their 'circles of friends.' Broadly speaking, this strategy yields short-term personal gains for a limited group of actors, but it undermines the long-term stability and the sustainability of the banking system. Bulgarian governments switched to a 'reform for the market' attitude after 1997, which I explain took place because of an important partisan change of the governing elites that reinforced the role of international actors and altered the elites' relationship with important domestic stakeholders.

\section{Theoretical Framework}

\section{Assessing the quality of banking sector legal reform}

To assess the quality of banking sector legal reform, I consider the starting point and goals of transition in eastern Europe. Then I identify benchmark legal reforms necessary to achieve those goals. Transitional countries in the region started out with a communist political system and a planned economy, and the broad goals of transition were to establish a liberal democracy and a market economy. According to the political economy literature developed in the last decade in the banking sphere it is desirable to (1) provide clear market entry and exit conditions (Kroszner, 1998; Fries, 2005); (2) introduce transparency in the banking system and ensure the ability of banks to function without excessive state intervention (Berglöf and Bolton, 2002; Fries, 2005); (3) guarantee central bank independence (Cukierman, 1992; Eijffinger and De Haan, 1996; Maxfield, 1998; Maliszewski, 2000; Johnson, 2006); and (4) establish independent banking oversight (Nord, 2000; Holthausen and Ronde, 2003). Those are key policy standards according to which I assess the quality of a country's banking sector legal framework. International actors such as the International Monetary Fund (IMF) and the World Bank have been adamant proponents of the so-called 'Washington consensus' policies ${ }^{3}$ in the region, 


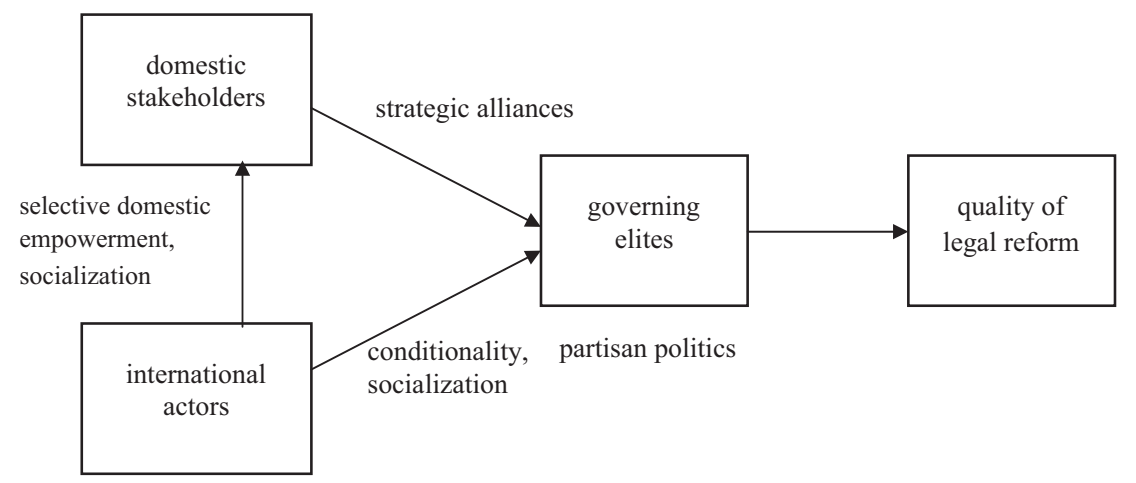

Figure 1 The influence of political processes on banking sector legal reform in the post-communist region.

including in the realm of banking reform. Thus, the benchmark legal reforms in my analysis reflect international pressure to adopt 'good practices' used in advanced industrialized economies such as introducing more competition in the sector, streamlining bankruptcy procedures, strengthening the central bank and bank supervision (Nord, 2000).

The three explanatory factors in my theoretical framework are the partisan coloration of governing elites, the strength and type of mobilized domestic stakeholders, and the involvement of international actors. Figure 1 provides an illustration of how those factors interact to produce policy change. In the argument developed here, the strategic considerations of different political actors drive legal change. By contrast, other explanations of policy change have focused on the initial conditions in which countries find themselves and salient policy legacies (De Melo et al., 1997; Ekiert and Hanson, 2003; Horowitz, 2004). ${ }^{4}$ I concentrate on the policy choices and strategies of a variety of political actors. Hence this article subscribes to the rational choice institutionalism approach, as outlined in Peter Hall and Rosemary Taylor's (1996) classification of the three new institutionalisms in contemporary political science. In addition, the analysis in the short case studies relies on mechanisms such as 'lock-in' effects and policy feedback loops that are used extensively in the historical institutionalist literature (Thelen, 1999). We now turn to a more detailed discussion of the three explanatory factors.

\section{Governing elites}

A widely recognized finding in the comparative politics literature with respect to partisan politics in the post-communist area is that center-right and 
reformed communist successor parties in power have performed better in the initiation and implementation of market-liberalizing economic reforms, compared to their unreformed communist counterparts (Haggard and Webb, 1994; Ekiert, 1996; Bunce, 2000; Grzymala-Busse, 2002; Vachudova, 2005). What might account for this association? The literature has emphasized two mechanisms that help explain the association between partisanship and the quality of economic reform. The first mechanism is party ideology. According to Valerie Bunce (1999), the correlation between center/right parties in power and better economic reform can be attributed to the ideological foundations of the right-wing opposition parties in the region. ${ }^{5}$ Because they rejected the economic policies pursued under communist rule, the opposition parties in most eastern European states have adopted a market-liberalizing economic agenda. The second mechanism is political competition. Milada Vachudova (2005) has shown that due to the increased quality of political competition, in countries where the right-wing opposition defeated the communist incumbents in the first post-1989 elections, the communist successor parties were forced to become more transparent, revised significantly their policy agenda, and endorsed market-liberalizing reforms in order to 'get back in the political game.' Thus, I expect the general proposition about the role of center-right and reformed communist successor parties in economic restructuring to be valid in the particular case of banking sector legal reform.

The argument about the salience of partisanship rests on the assumption that political parties are key actors in setting public policy. This may be a plausible hypothesis for many advanced industrialized states, but less so for post-communist countries (Kitschelt, 2000). Therefore, we need to investigate the influence of other groups such as organized business and economic interests on the policy positions of political parties in the region in light of findings about the general decline in political party membership over the last two decades (Mair and Biezen, 2001) and the weak social grounding of political parties in the region (Kopecky, 1995; Kitschelt, 2000; Lewis, 2001; Biezen, 2005, 156-160).

\section{Domestic stakeholders}

The relationship between the governing elites and mobilized domestic stakeholders is an important and neglected determinant of the quality of banking sector legal reform. By domestic stakeholders, I mean organized groups with a salient political or economic policy position such as business associations, labor unions, non-governmental organizations, and policy think tanks. Post-communist governments have formed strategic alliances with key domestic stakeholders in order to adopt and implement policy change. Below I outline the expected policy impact of two types of domestic stakeholders that 
are the most salient in banking sector reform - foreign investors and networks of industrial and financial managers from the previous regime. By contrast, labor organizations in the region have been weak and unable to influence policy change significantly (Crowley, 2002; Kubicek, 2004).

Scholars of political economy have established that inflows of foreign direct investment (FDI) have a positive effect on the performance of transitional economies in the post-communist region (Dunning and Narula, 1998). FDI provides both physical capital and employment opportunities that may not be available in the host economy. It is also an important mechanism of technology transfer (Jensen, 2003, 587). From a macro-economic perspective, FDI helps to offset current account and fiscal deficits. Moreover, FDI supplements the low domestic resources to finance both ownership change and capital formation during economic transition. Because of the significant benefits outlined above, attracting FDI has become an integral part of the development strategies in emerging economies (Jensen, 2003, 588).

What is the mechanism through which foreign direct investors may influence the path of banking sector legal reform? FDI is a long-term type of international capital flows, in contrast to short-term types such as portfolio investment. The purpose of FDI is to establish lasting commercial relations and exert a noticeable managerial influence in the foreign country (Barrell and Holland, 2000, 478). According to Lipschitz et al. (2002, 4), FDI is unlikely to be withdrawn in response to short-term market volatility. If a government can put in place institutional mechanisms that reduce political risk and ensure stable property rights and efficient financial intermediation, it will attract and retain more foreign investment (Jensen, 2003, 594; Li and Resnick, 2003, 178). Thus, the long-term commitment of FDI investors may motivate them to take an active part in enterprise decision-making and press the country's government for a more transparent and predictable business environment, including better banking sector laws and monitoring institutions.

I expect foreign investors to press for better banking sector laws. By contrast, I expect the persistence of financial and industrial manager networks from the previous regime to be associated with a worse quality of banking sector laws. What are some examples of rent-seeking domestic stakeholders that have mobilized against the introduction of comprehensive economic reforms, including in the banking sector? Joel Hellman (1998) has argued that the most significant threat to consolidating democracy and market economy does not come from the groups of structural reform 'losers' such as pensioners and heavy industry workers, but from the small group of partial reform 'winners' such as corrupt government officials and managers of state-owned enterprises. Branislav Slantchev (2005) has confirmed statistically this finding. According to Hellman, the post-communist experience has shown that reforms have been stalled by 'enterprise insiders who have become new owners only to 
strip their firms' assets; commercial bankers who have opposed macroeconomic stabilization to preserve their enormously profitable arbitrage opportunities in distorted financial markets; local officials who have prevented market entry into their regions to protect their share of local monopoly rents; and so-called mafiosi who have undermined the creation of a stable legal foundation for the market economy' (1998, 204).

Overall, I argue that a domestic alliance between center/right and reformed left governing elites in power and reform-oriented domestic stakeholders such as foreign investors and export-oriented domestic businesses will be associated with a good quality of banking sector legal reform. By contrast, an alliance between government elites from unreformed left communist successor parties in power and rent-seeking domestic stakeholders will perpetuate a worse quality of banking sector laws.

\section{International actors}

As shown in Figure 1, I argue that international actors influence legal reform of the banking sector via three channels: conditionality, domestic empowerment, and socialization. The use of conditionality by international actors has been investigated in detail by scholars and policy-makers (Mayhew, 1998; Schmitter, 2001; Vachudova, 2001; Spendzharova, 2003; Schimmelfennig and Sedelmeier, 2004; Vachudova, 2005). It entails a package of rewards and punishments attached to demands for specific policy changes. With respect to banking sector legal reform in the post-communist region, the demands of IMF conditionality include ensuring the independence of the central bank from political pressure; opening the sector to foreign investors and competition; strengthening bank supervision; and improving bankruptcy procedures (Bonin and Wachtel, 1999; Berglöf and Bolton, 2002; Bird and Willett, 2003). The European Union's (EU) conditionality is broader in nature and scope than IMF conditionality. For credible future members of the Union, the policy demands of the EU in the banking sphere are part of the comprehensive and compulsory pre-accession harmonization with EU law organized into 31 chapters of the acquis communautaire (Zielonka and Pravda, 2001; Cremona, 2003; Grabbe, 2006). Legal provisions concerning the banking sector regulatory environment feature in the following chapters: Economic and Monetary Union, Free Movement of Capital, Freedom to Provide Services, Financial Control, and Finance and Budgetary Provisions.

The second mechanism of international influence in my theoretical framework - domestic empowerment - means that some domestic groups or institutions increase their influence because they receive rhetorical and financial support from international actors that endorse a similar policy position (Kelley, 2004; Vachudova, 2005). For example, Juliet Johnson (2006) 
has shown that the central banks in the post-communist region have gained increasing independence since 1989 as a result of the ongoing integration in the Western financial system and international pressure to emulate the central banking model of advanced industrialized states. According to Johnson, 'These newly independent central banks began the post-communist period with shallow domestic support, and maintained this support primarily because of EU accession requirements' $(2006,368)$.

The third mechanism of international influence - socialization - presumes that actors follow what James March and Johan Olsen call the 'logic of appropriateness' $(1989,160)$. For the rationalist school, consequentialism and cost-benefit calculations underlie decision-making processes. ${ }^{6}$ By contrast, constructivist scholars argue that policy change will occur if international and domestic actors are involved in social interactions such as deliberation, persuasion, and learning (Checkel, 2001, 581). Rachel Epstein's work bridges the rationalist and the constructivist approaches. In her investigation of the transformation of central banking in eastern Europe, Epstein $(2006,1020)$ has established that policies such as central bank independence became institutionalized in diverse post-communist states because international institutions cultivated a social consensus in favor of central bank independence through persuasion, argumentation, and coalition building.

So far we saw a theoretical discussion of how three factors can shape legal reform of the banking sector. What configurations of the explanatory factors have driven legal change in my two empirical cases? I will use process tracing and comparative historical analysis to examine the dynamics of banking sector legal reform in Hungary and Bulgaria. In the short case studies below, I first outline significant changes in the banking sector legal framework. Then I analyze the particular configuration of governing elites, domestic stakeholders, and international actors that has produced the observed outcome.

\section{Legal Reform of the Banking Sector in Hungary, 1989-2005}

The analysis of banking sector legal reform in Hungary begins with an outline of the evolution of Hungarian banking laws since 1989. Earlier, I pointed out several key policy standards that I use to assess the quality of a country's banking sector legal framework. According to these benchmarks, it is desirable to (1) provide clear market entry and exit conditions; (2) introduce transparency in the banking system and ensure the ability of banks to function without excessive state intervention; (3) guarantee central bank independence; and (4) establish independent banking oversight. Figure 2 presents a timeline of important banking and financial sector laws adopted in Hungary after 1989. 


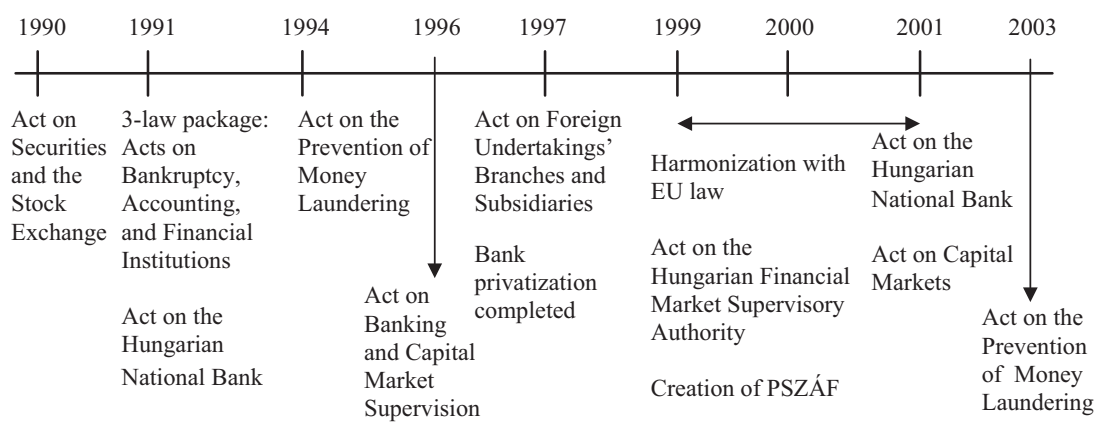

Figure 2 Timeline of important banking and financial sector laws in Hungary after 1989.

The Hungarian Parliament passed a package of three very important laws in late 1991 - the Acts on Bankruptcy, Accounting, and Financial institutions. According to the Bankruptcy Act, companies were obliged to shut down lossmaking activities and, if necessary, declare insolvency before special bankruptcy courts. The Act on financial institutions forced banks to make heavier provisions against risky loans and introduced international standards for capital adequacy. The Accounting Act established Western accounting principles to replace those used in the socialist planned economy (Denton, 1992). The three-law package brought to daylight the large financial liabilities on the balance sheets of Hungarian banks, still mostly state owned, and highlighted the need to somehow deal with those liabilities (Mihályi, 2006, personal interview). The Act on financial institutions limited any shareholder, including the state, to a $25 \%$ stake in the financial institution. This provision prevented enterprises from buying their own bank and, possibly, misusing the available capital. The new legislation set out capital adequacy requirements in accordance with Bank for International Settlements (BIS) norms. ${ }^{7}$

The 1991 Act on the Hungarian National Bank (HNB) established the basic rules for the operation of the HNB in line with the independent central bank framework. The German Bundesbank was one institution that Hungarian lawmakers had in mind when drafting the law (Soós, 2006, personal interview). The Act gave the National Bank the legal right to determine the course and choose the instruments for the implementation of monetary policy (Act LX of 1991). The amendments to the 1991 Act adopted in 1994 and 1997 redefined the relationship between the state budget and the National Bank. Previously, the provisions for granting budgetary financing to the government were rather lax. After the 1994 and 1997 amendments, however, there was little room left for any government to use the HNB as a 'cash cow.' As part of the preaccession legal harmonization with EU law, Hungarian law-makers adopted in 2001 a new Act on the HNB that reinforced its autonomy and ruled out the 
possibility for budgetary financing altogether. The law defined the achievement and maintenance of price stability as the primary objectives of the HNB (Act LVIII of 2001).

The emerging legal framework of the banking sector did have some flaws, but Hungarian policy-makers acted in a timely manner to correct them. For example, the Act on Bankruptcy did not guarantee adequate protection for creditors. The law allowed voluntary bankruptcy in the case of overdue debts and a 3-month moratorium on debt servicing without requiring interim negotiations with the creditors (Act IL of 1991; Act LXXXI of 1993). This legal arrangement opened the door for some companies that were not insolvent to suspend payments to their creditors (Várhegyi, 2002). After several banks incurred significant losses, the law was amended to correct the shortcomings (Act XXVII of 1997).

The 1996 Act on Hungarian Banking and Capital Market Supervision boosted the professionalism and independence of Hungarian bank and financial supervisors. Prior to 1996, separate supervisors were in charge of the different branches of financial services. At the same time, many banks operated as holding companies and offered a wide range of financial services. This loophole opened the possibility for some banks to evade the mandatory capital adequacy provisions against risky loans. In order to close the loophole, the 1996 Act merged banking and investment supervision (Act CXIV of 1996). In 2000, the creation of the Hungarian Financial Supervisory Authority, PSZÁF, added pension funds and insurance companies to the supervised entities to ensure a more comprehensive financial supervision (Act CXXIV of 1999).

The 1997 Act on Foreign Undertakings' Branches and Subsidiaries removed the barriers to market entry for foreign banks (Act CXXXII of 1997). The Act abolished a prior requirement that all foreign financial institutions obtain a formal permit from the Hungarian government to establish a bank subsidiary or buy more than a $10 \%$ stake in an existing bank. Taken together with the government's pro-active privatization policies, these legal measures paved the way for the quick and successful privatization of Hungary's banks, which needed an infusion of capital to cover the bad debts in their portfolios and meet the more stringent capital adequacy requirements.

As part of the legal harmonization with the EU's acquis communautaire, during the period 1999-2001 Hungarian law-makers brought the legal framework of the banking sector in full compliance with EU regulations and Basel core principles. ${ }^{8}$ Hungarian policy-makers synchronized the domestic financial legislation with that of the EU fairly quickly, provisionally closing the Economic and Monetary Union, Free Movement of Capital, Freedom to Provide Services, Financial Control, and Finance and Budgetary Provisions accession negotiations chapters well on schedule. In sum, the analysis so far has 
shown an incremental improvement of the Hungarian banking sector legal framework since 1989 and an overall good quality of the laws that were put in place - they largely meet the four criteria outlined in the beginning. Now we will examine the configuration of the three explanatory factors that has shaped the observed policy outcome.

\section{Configuration of governing elites, domestic stakeholders, and international actors}

Despite the existence of some drawbacks, Hungarian governments have set up market institutions and bolstered the regulatory capacity of the state. Decisionmakers' commitment to 'reforming for the market' has been crucial for the success of banking sector legal reform. Ministers of successive Hungarian governments have followed a consistent policy of defining property rights, restructuring state ownership, and maintaining financial stability in order to integrate Hungary swiftly in the European economy (Csaba, 2006, personal interview).

What are the sources of Hungarian elites' pro-market stance? Based on the partisanship and socialization arguments presented in the theoretical section, we expect sustained economic liberalization in Hungary. Hungarian communists had attempted to reform the party during communism. By 1990 they had renamed it Hungarian Socialist Party (MSZP) and embraced a pro-market agenda (Grzymała-Busse, 2002). Some experts who initiated the banking reforms in the early 1990s came from the center/right opposition, which is also associated with pursuing a reformist agenda (Ekiert, 1996; Vachudova and Snyder, 1997; Bunce, 2000; Vachudova, 2005). Even during communism, Hungarian economic elites could travel and interact with their Western European counterparts. As one of my interviewees pointed out, 'those opportunities for intellectual development and policy learning were crucial' in shaping the Hungarian elites' approach to transforming the economy (Mihályi, 2006, personal interview). Therefore, the constructivist mechanisms of socialization and persuasion through social interaction (see Checkel, 2001) are an additional explanation of why it has been easier to implement liberalizing banking reforms in Hungary.

The Appendix presents a brief chronology of Hungarian cabinets after 1989. The 1990 Antall government laid the foundations of successful legal reform in Hungary by introducing important market-oriented legislation such as the 1991 three-law package discussed earlier. Later, when the 1994 Socialist-liberal government (MSZP and SZDSZ) saw economic crisis coming, Prime Minister Gyula Horn tried to restore confidence in the country's economic management by nominating two reformers to key financial positions: Lajos Bokros as finance minister and Gyorgy Suranyi as president of the HNB. The two policymakers were the masterminds of the 1994-1995 austerity package that brought 
the Hungarian banking system back on its feet. Although political frictions existed between the Socialists and their rivals from FIDESZ, the alternation of political parties in power did not undermine the ongoing legal reforms of the banking sector. The 1998 FIDESZ government led by Victor Orban tightened banking supervision and financial oversight.

David Stark has shown that after looking for the correct mix of state and private ownership during communism, Hungarian elites were the first in the region to realize that 'the dominance of state ownership [was] fundamentally incompatible with market coordination' (1990, 351). Political economist László Csaba clarifies that in the beginning of transition, decision-makers' biggest concern about the state of the economy was its inefficiency. Communist economic planners had neglected the need for efficiency and sound managerial skills. Thus, the early economic reforms in Hungary were intended to boost all those aspects that were seen as missing (Csaba, 2006, personal interview).

The governing elites' initial commitment to 'reform for the market' entailed subsequent moves toward more economic liberalization. Drawing on Kethleen Thelen's (1999) discussion of historical institutionalism in comparative politics, I propose two dynamic feedback mechanisms that help explain institutional adaptation and change. The first feedback mechanism has to do with 'lock-in' effects: Once a set of institutions is put place, actors adapt their strategies in ways that reflect and reinforce the 'logic of the system' (Thelen, 1999, 394). The second feedback mechanism captures the significance of distributional effects. Institutions facilitate the organization and empowerment of certain domestic groups, while disarticulating and marginalizing others (Pierson, 1997; Thelen, 1999, 394). The strategic choice of Hungarian elites to adopt the market economy framework and introduce more private ownership in the early 1990s entailed further policy choices such as seeking international capital and initiating bank privatization. The distributional consequences of introducing more economic liberalization become evident when we consider the role of foreign investors in the Hungarian economy.

Successive Hungarian governments created strong incentives to attract foreign investors. They invested in building roads, communication networks, and streamlining the country's legal framework (Andor, 2000, 82). As one of my interviewees emphasized, 'Foreign investors made a big push for the development of the banking sector in the early 1990s. They were fed up with the poor infrastructure of the banks and the slow service' (Csoór, 2006, personal interview). Yudit Kiss $(1994,130)$ has shown that foreign capital was crucial for Hungary's economy in the beginning of transition. Greenfield foreign investors such as Audi, IBM, and Philips, as well as big domestic exporters privatized through stock exchange IPOs ${ }^{9}$ such as Richter (pharmaceuticals) and MOL (oil and gas) supported the development of an efficient domestic banking system (privatization data from Mihályi, 2000). By putting 
substantial pressure on the governing elites to implement comprehensive, Western-style banking reforms, domestic stakeholders such as foreign investors and large domestic exporters created a positive feedback loop, which further reinforced the pro-market inclination of Hungary's political and economic elites. For some time, Hungarian small and medium-sized enterprises (SMEs) had access to funds predominantly from government programs. The stabilization of the banking sector and the entry of foreign capital has been positive for SMEs as well (Király and Várhegyi, 1998).

As early as 1994, the Socialist Horn cabinet aimed to complete bank privatization by the end of its 4-year term and sought actively foreign investment (Andor, 2000, 81). By 1997, the state, which had dominated the banking system in 1994, retained a majority stake only in two banks, the Hungarian Development Bank and Eximbank. According to Andrew Barnes (2003), Hungarian banks were among the first in the region to withdraw from an active role in the enterprise sector in terms of both lending and ownership. The banks restructured their loan portfolios, jettisoned their holdings in weak firms, and pursued investment financing (Barnes, 2003, 539). Among the advantages of opening the banks to foreign ownership were introduction of fast and comprehensive banking services, harmonization with EU standards, and reduction of mismanagement (Bonin and Wachtel, 1999). The biggest development in the Hungarian banking sector after the end of privatization was the start of bank mergers in 2000.

In what ways have international actors influenced banking reform in Hungary? Hungarian decision-makers have considered advice from international organizations such as the IMF, World Bank, BIS, EU, and OECD, albeit selectively. The IMF has used conditionality to influence Hungarian economic policy since the 1980s because of the country's indebtedness. For example, in 1992 the IMF suspended Hungary's 3-year loan due to an excessive budget deficit. Hungary serviced its debt by issuing government bonds. However, continued cooperation with the IMF was quite important (Denton, 1993). In 1993, the government conceded to cut public sector spending and amend the legal framework to accelerate bank privatization. In return, the IMF disbursed $\$ 394$ million over 2 years. This released an additional $\$ 100$ million tranche from the World Bank for structural adjustment. László Csaba (1995) has described aptly the relations between Hungary and the IMF as a 'cordial discord.' According to Csaba (1995, 231), Hungarian governments had significant leeway in steering the domestic economy and followed IMF conditionality only in times of serious crisis. Hungary enjoyed a favorable position $v i s-a ̀-v i s$ the Fund because Hungarian elites were undoubtedly committed to servicing the foreign debt and implementing market liberalization.

The relationship between the EU and its eastern European neighbors was not well defined in the early 1990s. Yet it is clear that Poland, Hungary, and 
Czechoslovakia were the region's front-runners in seeking a closer association with the Union (Vachudova, 2005, 82). Initially, the EU reinforced in Hungary a domestic incentive structure that was already favorable for economic liberalization. After the start of formal negotiations, the Union's demands with respect to banking law harmonization were not controversial and Hungarian governments complied relatively quickly. Between 1999 and 2001, Hungary synchronized its key financial legislation with that of the EU, provisionally closing the Economic and Monetary Union, Financial Control, and Finance and Budgetary Provisions accession negotiations chapters well on schedule.

In Hungary, the IMF has pushed consistently for capital-friendly regulations such as low corporate taxes, tight monetary policy, and fast bankruptcy procedures. The other big proponent of conditionality in the region - the EU - has emphasized institution building. In illustration of the domestic empowerment mechanisms discussed earlier, a 1997 report outlined two main objectives for the EU with regards to financial sector reform in Central and eastern Europe. The first objective was to boost central banks' capacity to formulate and conduct monetary policy independently (Mörner, 1997). The second objective was to maintain a high degree of confidence in the banking system by creating independent supervisory agencies that would oversee the commercial banks (Mörner, 1997). In accordance with those two objectives, the EU accession process has empowered significantly the HNB and the Financial Supervisory Authority, PSZÁF.

In sum, banking sector legal reform in Hungary after 1989 exemplifies gradual improvement over time. The Hungarian case study shows that when government decision-makers recognize that reform can bring about considerable political and economic rewards, they are likely to engage in restructuring and improving the legal framework. The supportive stance of mobilized domestic stakeholders such as foreign investors and large domestic exporters who benefit from economic liberalization creates a positive feedback loop, thus reinforcing the elites' initial commitment to reform. International organizations such as the IMF and the EU have also assisted banking sector legal reform in Hungary through policy advice, financial aid, and continued interaction with the domestic elites.

\section{Legal Reform of the Banking Sector in Bulgaria, 1989-1997}

Two short case studies examine the politics of banking sector legal reform in Bulgaria. This article interprets the 1996/1997 financial crisis as a dividing line between the two periods of reform in the country. Figure 3 presents a timeline of important banking and financial sector laws adopted in Bulgaria after 1989.

There were frequent changes in the legal framework of the Bulgarian banking sector in the early 1990s indicating that policy-makers used a trial- 


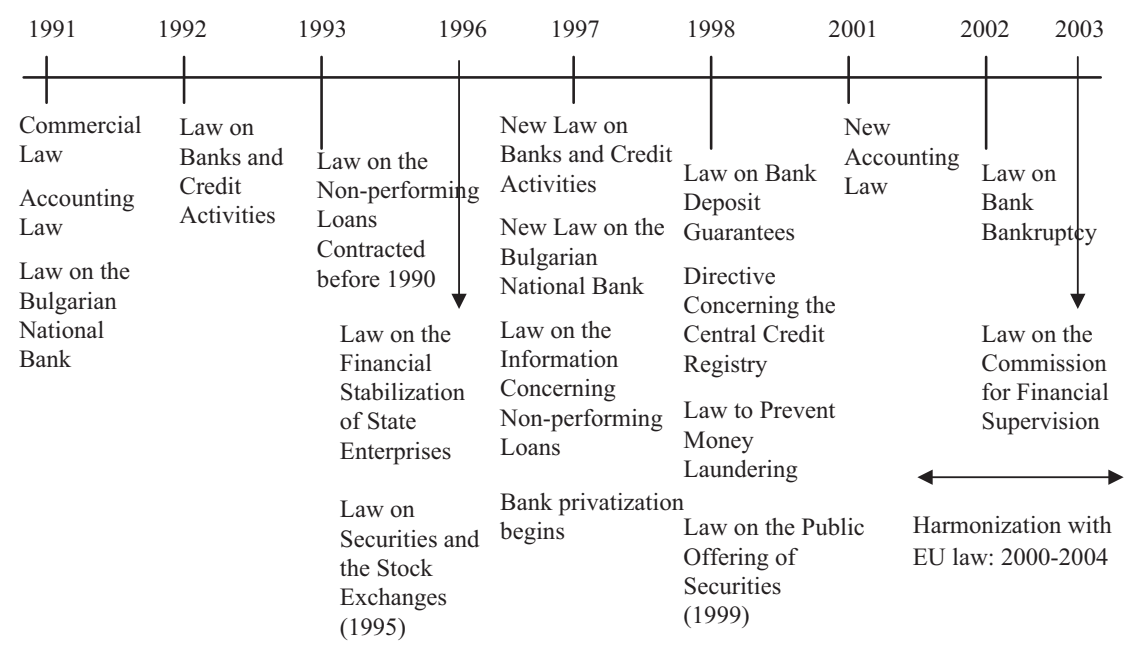

Figure 3 Timeline of important banking and financial sector laws in Bulgaria after 1989.

and-error approach to legal reform, rather than a strategic and comprehensive approach. For example, the Law on Banks and Credit Activities was adopted in 1992 under the reformist right-wing government led by Philip Dimitrov. Between 1992 and 1997, this law was changed nine times, and it was finally repealed in 1997 after the financial crisis in the country. Additional shortcomings of the early banking sector laws were the overly liberal licensing regime and the relatively small amount of initial capital required to open a bank. Thus, many small private Bulgarian banks were created by borrowing initial capital from the existing state banks (Hristova and Angelov, 2004, 74). The 1992 Law on Banking and Credit Activities allowed banks to exchange shares that enabled banks to operate legitimately by using one single pool of money. The banks that used this legal loophole such as Chastna Zemedelska $i$ Investiocionna Banka, TB Slavjani, Dobrudzhanska Banka, and Biznesbank were often involved in giving bad loans to their shareholders or relatives of the management (Hristova and Angelov, 2004; Stanchev, 2005, personal interview). At the same time, the 1990s legal framework deterred foreign banks from entering the domestic market. By 1994, only the Greek Xios Bank and the Dutch $I N G$ Bank had set up branches in Bulgaria.

In the early 1990s, Bulgarian banks operated under what economists have called 'soft budget constraints' (Kornai, 1986). Pressured by politicians, bankers extended sizeable loans to loss-making state enterprises. As a consequence, $75 \%$ of all bank loans in Bulgaria were classified as 
non-performing in 1995 (Walko, 2004). The 1991 Law on the Bulgarian National Bank (BNB) made the BNB responsible for monitoring the activities of the commercial banks, collecting information, and overseeing the stability of the banking system (Zakon za BNB, Article 44). The law stipulated that the BNB should be free from political interference, but it also allowed the government to request funds from the central bank in case of a severe necessity. Thus, responding to the government's requests, the BNB kept providing liquidity to the market in the mid-1990s to prevent banks from failing. But its interventions did not alleviate the underlying problems of the banks. At the end of 1995, only four of the 47 banks operating in Bulgaria at the time reported end-of-the-year profits (Hristova and Angelov, 2004, 77). According to economists Assenka Hristova and Georgi Angelov (2004), the recapitalization of the Bulgarian banks was the most costly bank bailout in the post-communist region. Overall, bank recapitalization cost Bulgarian taxpayers about $\$ 4$ billion (Todorova and Raeva, 1997). In 1995, given the lack of adequate bankruptcy legislation, the BNB took a pro-active position and revoked the licenses of two troubled banks. However, when the banks appealed against the measure before the Bulgarian Supreme Court, the Court reversed the BNB decision (Kapital, 1997).

Which laws made possible the rapid growth of bad loans in the Bulgarian economy in the early 1990s? In accordance with Article 4 of the 1993 Law for Settling the Non-performing Loans Contracted before 31 December 1990, the Bulgarian Financial Ministry issued long-term government bonds in October 1993 denominated both in leva, the national currency, and dollars. Those government bonds, also known as ZUNK bonds, provided a legal way for the government to assume responsibility for the loans contracted by state-owned enterprises before 1990 (Hristova and Angelov, 2004, 75-76). Thus, the eligible enterprises became mostly debt-free. But instead of restructuring and seeking ways to be profitable, most state-owned enterprises negotiated new loans with the banks and continued to run losses (Hristova and Angelov, 2004, 77).

We saw that Hungarian policy-makers aimed for generality and consistency in the laws. By contrast, Bulgarian legislators adopted laws to address the arising problems on an ad hoc basis. Let us return to the four policy standards that I use to assess the quality of a country's banking sector legal framework. The analysis has shown that the 1991 Bulgarian Commercial Law and the 1992 Law on Banks and Credit Activities did not provide clear market entry and exit conditions. Furthermore, the laws on non-performing loans and the financial stabilization of the state enterprises demonstrated the deficiencies of the Bulgarian banking sector legal framework in terms of ensuring transparent bank operations without excessive state intervention. Finally, the law on the BNB did not provide sufficient guarantees for the central bank's independence from political pressure. 


\section{Configuration of governing elites, domestic stakeholders, and international actors}

What configuration of governing elites, domestic stakeholders, and international actors in Bulgaria stalled banking sector legal change in the early 1990s? The Bulgarian banking system was transformed from a one-tier to a two-tier one in 1989, comprised of the BNB and the new commercial banks. However, the development of Bulgarian banks was severely hindered by the distorted incentives in the banking system. Of the 10 relatively large banks in Bulgaria at the end of 1995, nine were state-owned (Barisitz, 2001). In their analysis of bank performance and credit practices in Bulgaria before the 1996/1997 crisis, Kenneth Koford and Adrian Tschoegl (1997) have detected widespread insider crediting, a vague legal environment, and rampant corruption. At times, it seemed like Bulgaria was cleaning up its act and taking the path of reforms. In 1992, the newly elected Dimitrov government demonstrated eagerness to catch up with the Central European front runners (Dimitrov, 2005, personal interview). Key decision-makers discussed what reforms were necessary with officials from PHARE, ${ }^{10}$ the World Bank, and the IMF. In addition, experts from Poland, the Czechoslovakia, and Hungary shared their insights about economic reform (Dempsey, 1992). But before this government could implement its ambitious action program, it lost a parliamentary vote of confidence and resigned.

Based on the partisanship and socialization arguments presented in the theoretical section, we do not expect to see decisive moves toward economic liberalization in Bulgaria in the early 1990s. When the right-wing opposition party, the Union of Democratic Forces, formed in late 1989, it lacked sufficient popular support to form a government backed by a stable parliamentary majority. In contrast to the MSZP that pursued genuine reform, the Bulgarian Socialist Party (BSP) only changed its name from communist to socialist but failed to adjust its goals and methods to the standards of liberal democracy (Vachudova and Snyder, 1997). During communism too, Bulgarian elites were closely allied with the Soviet leadership and had little exposure to Western economic thought. As more or less those same elites constituted the early BSP governments, they had strained relations with international promoters of economic liberalization. The constructivist mechanisms of socialization and persuasion (see Checkel, 2001) were confronted with hostile domestic conditions in Bulgaria until 1997 and could not alter domestic policy.

The Appendix presents a brief chronology of Bulgarian cabinets after 1989. When the 1994 Videnov government took office, reform efforts practically halted. The Socialists claimed that they had won a mandate for a 'sociallyoriented' transition (Lilov, 2004), but policy-wise this entailed subsidizing the state enterprises and pressuring the banks to extend more bad loans. Venelin Ganev (2001a) has investigated one of the prime examples of 'friendly circles' 
in Bulgaria - the financial-industrial conglomerate Multigroup. In the period 1992-1996, Multigroup gained control over more than 120 Bulgarian companies in sectors such as metallurgy and mining, engineering, petrochemicals, oil and gas, gas distribution, and tourism. Ganev (2001a, 5-8) points out that the majority of the company's 20 general directors were ex-directors of state-owned enterprises, ministers, and deputy ministers who served before 1989 or in the post-1989 Socialist cabinets. In his analysis of Multigroup's rise to one of the most powerful private economic actors in the Bulgarian economy after 1989, Ganev concludes that 'the profits of the private conglomerate are invariably accompanied by losses of its state-owned partners' (2001a, 8).

Drawing on Hellman's (1998) argument about the politics of partial reform, in the theoretical section, I argued that the persistence of networks of financial and industrial managers from the previous regime would be associated with a worse quality of banking sector legal reform. What are the implications of the political and economic clout of such 'friendly circles' for the state and the economy? The short case study of Bulgaria until 1997 has shown that during the dynamic period of state-led creation of property rights and ownership restructuring, the governing elites have the ability to highjack state resources and deliberately weaken the state's monitoring and regulatory capacity. For example, Ganev $(2001 b, 391)$ has demonstrated how the early Socialist governments in Bulgaria de-institutionalized the state agencies that monitored the economy. This paved the way for what he calls 'selective privatization' of state assets to insiders with personal links to ministers and high-ranking state officials.

Like in Hungary, international actors advocated economic liberalization in Bulgaria. However, conditionality did not work in Bulgaria in the early 1990s. I attribute the weakness of this mechanism not to a lack of engagement on the part of the international community, but to a lack of receptivity on part of the Bulgarian governments. For example, ex-Prime Minister Andrey Lukanov stated before the arrival of IMF representative An McGurk, 'We should not accept the dictate of the international financial institutions with respect to the loans to state-owned enterprises and the status of the social welfare system' (Kapital, 1998). The so-called 'Rahn-Utt Plan' illustrates the limited impact of international advisers. The report is named after two US economists, Richard Rahn and Ronald Utt, who were commissioned to outline strategies for Bulgaria's transition to market economy by Prime Minister Lukanov in 1990. The research team suggested rapid market-oriented reforms in three interrelated areas: creation of property rights; privatization of the state enterprises; and reform of the taxation, banking, and financial systems (Rahn and Utt, 1990). According the Alexandar Lilov, a prominent BSP politician throughout the 1990s, the Rahn-Utt report was deemed unacceptable by many BSP party officials and, eventually, was shelved $(2004,524)$. But international 
actors became a very important factor in Bulgarian financial policy after the $1996 / 1997$ crisis and the subsequent early elections that brought to power Ivan Kostov's right-wing government. We now turn to the second period of Bulgaria's banking reforms.

\section{Legal Reform of the Banking Sector in Bulgaria, 1997-2005}

The main legacy of the Videnov BSP government was widespread economic mismanagement that gave rise to shortages and culminated with a severe financial crisis in the winter of 1996/1997. The two most visible dimensions of the financial turmoil were a currency crisis and a bank crisis. The national currency, lev, depreciated rapidly in 1995. Inflation was skyrocketing. Firms and citizens rushed to convert all their leva assets into foreign currency, but that was in short supply. Due to the absence of a variety of investment opportunities in the early 1990s, people held their savings mostly in the banks (Dobrinsky, 2000, 590). As the public's confidence in financial institutions started to erode in late 1995, citizens sought to withdraw their savings, only to find that banks did not have sufficient liquidity to meet depositors' demands (Dobrinsky, 2000, 591). In the winter of 1996/1997, citizens organized unprecedented in scale and duration protests against the economic policy of the BSP government. In January 1997, more than 10,000 protesters blockaded the building of the Bulgarian Parliament, demanding that the Videnov government step down immediately. Eventually, the government announced on 4 February 1997 that it would resign, thus paving the way for early elections in April 1997.

The international political economy literature has shown that severe crises can trigger policy reform (Haggard and Kaufman, 1992; Bruno, 1993; Hall, 1993; Huber and Stephens, 1998; McDermott, 2004). An investigation of the effect of crisis on policy reform is beyond the scope of this article, but it is worthwhile to point out that in Bulgaria the pace and quality of banking legal reform increased after the crisis and the political turnaround. In 1997, the IMF approved a $\$ 582$ million stand-by credit so that Bulgaria could begin to tackle the crisis. The Fund demanded the implementation of an austerity package including significant amendments of Bulgaria's banking sector legal framework (Financial Times, 1997; Miller and Petranov, 2001).

Below, I outline important features of new Law on Banks and Credit Activities, the Directive Concerning the Central Credit Registry, the Law on Bank Bankruptcy, and the Law for the Bulgarian National Bank. Those laws corrected many of the shortcomings in the pre-1997 banking sector legal framework with respect to setting clear market entry and exit conditions and introducing transparency in the banking system. Figure 3 in the preceding section presented a timeline of important banking and financial sector laws adopted in Bulgaria after 1989. The 1997 Law on Banks and Credit Activities established stricter criteria 
for the required education and experience of bank managers (Zakon za bankite, Article 9). This law introduced a more rigorous licensing regime that increased the power of the central bank (BNB) to grant and revoke bank licenses (Zakon za bankite, Article 12-17; Miller and Petranov, 2001, 54). The 1997 Law on Banks and Credit Activities was also designed in order to initiate bank privatization. In 1998, the Directive Concerning the Central Credit Registry mandated the creation of a Central Credit Registry. Since 20 January 1999, commercial banks have been obliged to report to this registry all clients borrowing more than 10 million leva (roughly equal to $\$ 6$ million) and the amount of the loan. In turn, the BNB disseminates the collected information.

In 1999, the BNB formed a working group to draft a new Bankruptcy Law (Dimitrova, 1999). At the time, bank bankruptcy procedures took place according to the general Article 38 'Insolvency' of the Commercial Law. The improved Law on Bankruptcy was adopted in 2002. The 1991 Law for the Bulgarian National Bank was repealed during the 1996-1997 crisis. The new 1997 Law for the Bulgarian National Bank increased significantly the independence of the central bank. As part of the harmonization with EU law, Bulgarian law-makers adopted a new Accounting Law in 2001, a new Law on the Commission for Financial Supervision in 2003, and a new Capital Adequacy Directive in 2004. In 2002, Bulgarian banks began to use international accounting standards to meet the requirements of the 2001 Accounting Law. The 2003 Law on the Commission for Financial Supervision established integrated financial supervision including securities, insurance, pension, and investment funds. In addition, bank deposit guarantees were increased to meet international standards (Antonova, 2005).

\section{Configuration of governing elites, domestic stakeholders, and international actors}

I argue that the improvement of the banking sector legal framework in Bulgaria after 1997 resulted from the partisan change of governing elites following the early elections and the receptivity of the new government to the policy recommendations of international actors. Once the BSP was ousted from power, the clientelistic networks between political elites and rent-seeking domestic stakeholders started to break down without access to the financial resources provided by the state. The right-wing Kostov government began to alter the legal environment and seek allies who would support its economic reform program such as foreign investors and domestic business actors. Bulgarian governments post-1997 have been trying to contain corruption and clientelism, although those are still present in the country. The EU accession process has put additional pressure on Bulgarian institutions to be more transparent. The pattern of domestic alliances built by the Kostov government and the centrist Sakskoburggotski cabinet that succeeded it resembles that 
observed in the Hungarian case. The Appendix presents a brief chronology of Bulgarian cabinets after 1989. The three Bulgarian governments after 1997 have promoted a stronger role of market mechanisms in the economy. Serving their full terms has provided sufficient time to 'lock in' the institutional changes and create positive feedback loops reinforcing economic liberalization.

Large foreign investors such as Marvex - Spain, Solvay - Belgium, Interbrew - Belgium, UniCredito - Italy, Bank Austria Creditanstalt - Austria had significant leverage in pressuring the reformist governments for a better regulatory environment, including in the banking sector. Some foreign investors entered Bulgaria in 1994 and 1995 regardless of the imperfections in the legal framework as part of their strategy to expand operations in eastern Europe, but most investors came after 1997 when the privatization process accelerated. They preferred to operate in transparent and corruption-free business conditions and called for the adoption of international business practices and standards (Ditlbacher et al., 2002; Djarova, 2004). SMEs did not have the financial clout of foreign investors and were not sufficiently organized to influence the government. Still, better banking laws and a competitive banking environment have been beneficial for the SMEs as well, because they can borrow at a lower cost and are less vulnerable to liquidity crowding-out, which was common during the 'partial reform' period in the early 1990s (Budina et al., 2000).

In the realm of banking, the recommendations of international actors converged: The IMF, EU, and World Bank insisted on initiating bank privatization (Peev, 1998). Until 1997, the state-run Bank Consolidation Company, formed in 1992 to improve the functioning of the banking system, had not completed a single privatization deal. In the period 1997-2000, the Kostov government sold $67 \%$ of all state assets eligible for privatization, compared to $11 \%$ privatized by preceding governments. The Kostov and Sakskoburggotski governments completed bank privatization. By 2003, the share of private ownership in the banking sector had reached $97.6 \%$. Only two banks remained state owned: the Ministry of the Economy-owned Nasurchitelna Banka and Sofia municipality-owned Obshtinska Banka (Anglelov and Chobanov, 2004). As in Hungary, the entry of foreign banks generally improved the quality and availability of banking products and services, and reduced the instances of mismanagement.

The IMF deserves significant credit for Bulgaria's economic stabilization after 1997 (Barisitz, 2001). In compliance with the Fund's conditionality, Bulgaria entered into a currency board and introduced a fixed exchange rate. As part of the currency board arrangements, the BNB could no longer bail out the government (Miller and Petranov, 2001, 60-63). IMF conditionality and the currency board helped to curb inflation, promote fiscal discipline, and limit clientelistic lending practices (Nenovsky and Rizopoulos, 2003; Zaimov and Hristov, 2003; Hristov, 2004). 
The EU also influenced reforms in Bulgaria through its pre-accession conditionality. The release of the European Commission's opinion on Bulgaria's application for membership in 1997 coincided with the change of governing elites. The reformist Kostov cabinet paid close attention to the EU's recommendations and moved Bulgaria from the path of partial reform to the path toward EU membership. It followed the Commission's recommendations for legal changes in order to improve the economic environment in the country (European Commission, 1997, 37). In illustration of the domestic empowerment mechanism discussed earlier, EU accession has boosted the independence of the BNB. Nikolay Nenovsky et al. $(2003,27)$ have shown that after 1997, the BNB has exerted significant influence over the commercial banks and promoted strict rules for risk exposure. The credible prospect for EU membership has helped sustain economic liberalization as a beneficial long-term strategy in Bulgaria, because it would bring about closer ties with European investors, an inflow of aid for implementing the acquis communautaire, and an improved credit standing on international financial markets. The 2001 centrist government of Simeon Sakskoburggotski kept the course of economic liberalization and harmonization with EU laws, including in the banking sphere.

In short, the two case studies on Bulgaria have demonstrated that in the early 1990s Bulgarian governing elites were exposed to the same international policy advice as their Hungarian counterparts. However, the weakness of the political parties and domestic stakeholders who favored economic liberalization allowed rent-seeking actors to establish a 'reform for our friends' alliance in pursuit of narrow personal interests. The widespread economic mismanagement of the Videnov government led to a severe financial crisis in the winter of 1996/1997 that shook the status quo in Bulgarian politics. I argued that the observed significant improvement of the banking sector legal framework after 1997 resulted from an important partisan change of the governing elites that reinforced the role of international actors and created a pattern of domestic alliances in favor of economic liberalization. International actors such as the IMF and the EU had advocated economic liberalization before the watershed electoral change of 1997, but only after 1997 did Bulgarian politicians consider their policy recommendations. In order to sustain economic liberalization, the governing elites reached out to foreign investors and domestic business groups that favored transparency and closer ties with Western market economies.

\section{Conclusion}

Legal reform of the banking sector is a crucial component of economic liberalization and reveals the challenges of building market institutions in the post-communist region. This article illuminated the political processes that 
have shaped banking sector legal reform, given the persistence of old economic practices and patterns of political alliance. Since 1989, the reform trajectories of post-communist states have differed. One set of cases is exemplified by Hungary that took a path of incremental improvement of the legal framework. The Hungarian case demonstrated that reform front-runners introduced more private ownership in the economy, but they also enhanced the regulatory capacity of the state. Another set of cases is exemplified by Bulgaria until 1997 where partial reforms weakened the regulatory capacity of the state and generated benefits only for a small group of political and economic actors. Influential members of the Bulgarian political elite were able to transform their temporary access to political power into long-term economic gains and influence.

Scholars of democratization have enhanced our knowledge of 'hybrid regimes' that combine characteristics of democratic and authoritarian governance (Karl, 1995; Diamond, 2002; Levitsky and Way, 2002; Vachudova, 2005). This article has improved our understanding of 'hybrid regimes' that are also 'partial reform' economies such as Bulgaria until 1997. The analysis of banking sector legal reform in Bulgaria highlighted the importance of having governing elites who are knowledgeable and willing to undertake thorough economic restructuring. What countries like Bulgaria needed during transition was a far-reaching transformation of the economy and a different structure of the domestic incentives. In particular, IMF conditionality and the credible prospect for EU membership created opportunities for an inflow of investment, increase in trade, and access to international aid and loans that simply did not exist in Bulgaria in the early 1990s. This article also underscored the importance of reinforcing the rule of law. The analysis has shown that successful legal reform creates a more pluralistic and competitive economic environment that can accommodate a variety of economic actors.

\section{About the author}

Aneta B. Spendzharova graduated from the University of North Carolina, Chapel Hill, USA in 2007 with a Ph.D. in Political Science. In 2008, she will be a post-doctoral researcher at the Institute for Advanced Studies in Vienna, Austria. Her research focuses on regulatory reform in the post-communist region, international conditionality, and European integration.

\section{Notes}

1 I am grateful to Milada Vachudova, Liesbet Hooghe, Georg Vanberg, John Stephens, members of the Comparative Politics Working Group at UNC - Chapel Hill, and three anonymous CEP reviewers for invaluable comments and feedback. My research has been supported by grants from the European Union Center of Excellence at UNC - Chapel Hill and the Graduate 
School at UNC — Chapel Hill. Catherine de Vries has provided very helpful suggestions while I was revising this manuscript. I appreciate the hospitality and advice of Bobby Phillips, Ivo Sardamov, and Cosmina Tanasoiu at the American University in Bulgaria and faculty at the Central European University in Hungary during my field research.

2 I thank the anonymous $C E P$ reviewer who suggested considering more carefully the role of the state during the process of ownership change in the banking sector.

3 Developed for Latin American countries in the late 1980s, the 'Washington Consensus' policy package was subsequently extended to other transitional countries, including the postcommunist states (Ortiz, 2003, 15; Williamson, 2003). It has generated much controversy after countries that implemented the prescribed policies were hit by major economic crises such as the 'tequila crisis' in Mexico in 1994-1995 and Argentina's financial crisis in 2001. John Williamson (1994) has outlined 10 policy objectives of the 'Washington consensus': fiscal discipline; reorientation of public expenditure; tax reform (broadening the tax base and cutting marginal rates); financial liberalization (ending interest rate controls); unified and competitive exchange rates; trade liberalization (reducing tariffs and eliminating non-trade barriers); liberalization of foreign investment; privatization; deregulation; and securing property rights.

4 I thank an anonymous $C E P$ reviewer for bringing up this point.

5 See also Hilary Appel (2000) for an informative discussion of the impact of ideology on economic liberalization in the post-communist region.

6 It is beyond the scope of this paper to discuss the debate between the rationalist and the constructivist school. However, two excellent articles that provide an overview of what is at stake in this debate are Finnemore and Sikkink's (2001) article on constructivism in international relations and comparative politics and Jupille et al. (2003) survey article on integrating rationalism and constructivism in the study of the European Union.

7 The Bank for International Settlements (BIS) is a Basle-based grouping of central banks.

8 Basel core principles set international standards for measuring bank capital adequacy. They are drafted by bank supervisors and central bankers from 13 countries making up the Basel Committee on Banking Supervision.

9 IPO stands for Initial Public Offering. This is a procedure to take a company public, allowing investors to buy the company's stock.

10 PHARE was one of the first EU assistance programs for eastern Europe.

\section{References}

Andor, L. (2000) Hungary on the Road to the European Union: Transition in Blue, Westport, CT: Praeger.

Anglelov, G. and Chobanov, D. (2004) 'Vavezhdaneto na valutnija bord - osnova na ikonomicheskata stabilizacija', in K. Stanchev (ed.) Anatomija na prehoda. Stopanska politika na Balgaria ot 1989 do 2004, Sofia: Ciela Publishing, pp. 99-110.

Antonova, A. (2005) 'Predpazliva reforma v zashtitata na vlogovete?', Kapital, issue 10.

Appel, H. (2000) 'The ideological determinants of liberal economic reform. The case of privatization', World Politics 52(4): 520-549.

Barisitz, S. (2001) 'The development of the Romanian and Bulgarian banking sectors since 1990', Austrian National Bank Article Working Paper.

Barnes, A. (2003) 'Comparative theft: context and choice in the Hungarian, Czech, and Russian transformations, 1989-2000', East European Politics and Societies 17(3): 533-565.

Barrell, R. and Holland, D. (2000) 'Foreign direct investment and enterprise restructuring in Central Europe', Economic of Transition 8(2): 477-504. 
Bartlett, D. (1997) 'The political economy of privatization: property reform and democracy in Hungary', East European Politics and Societies 6(1): 72-119.

Berglöf, E. and Bolton, P. (2002) 'The great divide and beyond: financial architecture in transition', Journal of Economic Perspectives 16(1): 77-100.

Bird, G. and Willett, T. (2003) 'IMF conditionality, implementation and the political economy of ownership', Unpublished Manuscript.

Bonin, J. and Wachtel, P. (1999) 'Lessons from bank privatization in Central Europe', World Bank and Federal Reserve of Dallas Conference on Bank Privatization (US); Dallas, Texas; 19-20 November.

Bruno, M. (1993) Crisis, Stability, and Economic Reform, Oxford: Oxford University Press.

Budina, N., Garretsen, H. and de Jong, E. (2000) 'Liquidity constraints and investment in transition economies. The case of Bulgaria', Economics of Transition 8(2): 453-475.

Bunce, V. (1999) Subversive Institutions. The Design and the Destruction of Socialism and the State, Cambridge: Cambridge University Press.

Bunce, V. (2000) 'Comparative democratization. Big and bounded generalizations', Comparative Political Studies 33(6-7): 703-734.

Checkel, J. (2001) 'Why comply? social learning and European identity change', International Organization 55(3): 553-588.

Comisso, E. (1991) 'Property rights, liberalism, and the transition from "actually existing" socialism', East European Politics and Societies 5(1): 162-188.

Cremona, M. (ed.) (2003) The Enlargement of the European Union, Oxford: Oxford University Press.

Crowley, S. (2002) 'Explaining labor quiescence in postcommunist Europe', Biannual Conference of Europeanists (US); Chicago, Illinois; 15-17 March.

Csaba, L. (1995) 'Hungary and the IMF: the experience of a cordial discord', Journal of Comparative Economics 20: 211-234.

Csaba, L. (2006) Personal interview, Budapest, Hungary, 11 April.

Csoór, K. (2006) Personal interview, Budapest, Hungary, 12 April.

Cukierman, A. (1992) Central Bank Strategy, Credibility, and Independence, Cambridge: MIT Press.

De Melo, M., Denizer, C., Gelb, A. and Tenev, S. (1997) 'Circumstance and choice. The role of initial conditions and policies in transition economies', World Bank Working Paper.

Dempsey, J. (1992) 'Wayward Bulgaria returns to path of reform', Financial Times, 9 April.

Denton, N. (1992) 'Survey of Hungary: reforms spark a credit crunch', Financial Times, 29 October 1992.

Denton, N. (1993) 'IMF puts conditions on Hungary credit accord', Financial Times, 6 May.

Diamond, L. (2002) 'Thinking about hybrid regimes', Journal of Democracy 13(2): 21-35.

Dimitrova, D. (1999) 'BNB podgotvja nov zakon za bankovata nesustojatelnost', Kapital, issue 4.

Dimitrov, P. (2005) Personal interview, Blagoevgrad, Bulgaria, 26 September.

Ditlbacher, U., Fidrmuc, J. and Walter, P. (2002) 'Private capital flows to emerging markets in the 1990s and their impact on financial markets', Financial Stability Report 4 of Austrian National Bank.

Djarova, J. (2004) Cross-Border Investing: The Case of Central and Eastern Europe, Dordrecht: Kluwer Academic Publisher Group.

Dobrinsky, R. (2000) 'The transition crisis in Bulgaria', Cambridge Journal of Economics 24: 581-602.

Dunning, J.H. and Narula, R. (1998) 'Explaining international R\&D alliances and the role of governments', International Business Review 7(4): 377-398.

Eijffinger, S.C.W. and De Haan, J. (1996) 'The political economy of central bank independence', Princeton Special Papers in International Economics no.19.

Ekiert, G. (1996) The State Against Society, Princeton, NJ: Princeton University Press. 
Ekiert, G. and Hanson, S.E. (eds.) (2003) Capitalism and Democracy in Central and Eastern Europe, Cambridge: Cambridge University Press.

Epstein, R.A. (2006) 'Cultivating consensus and creating conflict. international institutions and the (de)politicization of economic policy in postcommunist Europe', Comparative Political Studies 39(8): 1019-1042.

European Commission (1997) 'Commission opinion on Bulgaria's application for membership of the European Union', Brussels, 15 July.

Evans, P. (1992) 'The State as Problem and Solution: Predation, Embedded Autonomy, and Structural Change', in S. Haggard, R. Kaufman and P. Evans (eds.) The Politics of Economic Adjustment: International Constraints, Distributive Conflicts and the State, Princeton: Princeton University Press.

Filer, R., Gylfason, T., Jurajda, S. and Mitchell, J. (2001) 'Markets and growth in the postcommunist world', Unpublished Manuscript.

Financial Times (1997) 'The Balkan slowcoaches', 27 August.

Finnemore, M. and Sikkink, K. (2001) 'Taking stock: the constructivist research program in international relations and comparative politics', Annual Review of Political Science IV: 391-416.

Fries, S. (2005) 'Politics of banking reform and development in the post-communist transition', EBRD Working Paper.

Ganev, V. (2001a) 'The Dorian Gray effect: winners as state breakers in postcommunism', Communist and Postcommunist Studies 34(1): 1-25.

Ganev, V. (2001b) 'The separation of party and state as a logistical problem: a glance at the causes of state weakness in postcommunism', East European Politics and Societies 15(2): 389-420.

Gould, J.A. (2003) 'Out of the blue? democracy and privatization in postcommunist Europe', Comparative European Politics 1: 277-311.

Grabbe, H. (2006) The EU's Transformative Power: Europeanization Through Conditionality in Central and Eastern Europe, New York: Palgrave Macmillan.

Grosfeld, I. (1991) 'Privatization of state enterprises in Eastern Europe: The search for a market environment', East European Politics and Societies 5(1): 142-161.

Grzymała-Busse, A. (2002) Redeeming the Communist Past, Cambridge: Cambridge University Press.

Haggard, S. and Kaufman, R. (eds.) (1992) The Politics of Economic Adjustment, Princeton: Princeton University Press.

Haggard, S. and Webb, S. (1994) 'Introduction', in S. Haggard and S. Webb (eds.) Voting for Reform: Democracy, Political Liberalization, and Economic Adjustment, New York: Oxford University Press.

Hall, P.A. (1993) 'Policy paradigms, social learning, and the state: the case of economic policymaking in Britain', Comparative Politics 25(3): 275-296.

Hall, P.A. and Taylor, R. (1996) 'Political science and the three new institutionalisms', Political Studies XLIV: 936-957.

Hellman, J. (1998) 'Winners take all: the politics of partial reform in postcommunist-transitions', World Politics 50(2): 203-234.

Hoff, K. and Stiglitz, J.E. (2004) 'After the big bang? obstacles to the emergence of the rule of law in post-communist societies', The American Economic Review 94(3): 753-763.

Holthausen, C. and Ronde, T. (2003) 'Cooperation in international banking supervision: a political economy approach', European Central Bank Working Paper No. 316.

Horowitz, S. (2004) 'Structural sources of post-communist market reform: economic structure, political culture, and war', International Studies Quarterly 48: 755-778.

Hristov, K. (2004) 'Parichnijat savet: the only game in town', Bulgarian National Bank Discussion Paper. 
Hristova, A. and Angelov, G. (2004) 'Balgarskijat bankov sector i finansovata kriza', in K. Stanchev (ed.) Anatomija na prehoda. Stopanska politika na Balgaria ot 1989 do 2004, Sofia: Ciela Publishing.

Huber, E. and Stephens, J. (1998) 'Internationalization and the social democratic model: crisis and future projects', Comparative Political Studies 31(3): 353-398.

Jensen, N. (2003) 'Democratic governance and multinational corporations: political regimes and inflows of foreign direct investment', International Organization 57: 587-616.

Johnson, J. (2000) A Fistful of Rubles. The Rise and Fall of the Russian Banking System, Ithaca: Cornell University Press.

Johnson, J. (2006) 'Two-track diffusion and central bank embeddedness: the politics of Euro adoption in Hungary and the Czech Republic', Review of International Political Economy 13(3): 361-386.

Jupille, J., Caporaso, J. and Checkel, J. (2003) 'Integrating institutions: rationalism, constructivism, and the study of the European Union', Comparative Political Studies 36(1/2): 7-40.

Kapital (1997) 'Badeshteto na bankite ostava v gasta magla', issue 49.

Kapital (1998) 'Trite Godini na An McGurk', issue 44.

Karl, T. (1995) 'The hybrid regimes of Central America', Journal of Democracy 6(3): 72-87.

Kelley, J.G. (2004) Ethnic Politics in Europe. The Power of Norms and Incentives, Princeton NJ: Princeton University Press.

Király, J. and Várhegyi, É. (1998) 'SME-Finance - An SME-Bank? Possibilities and Constraints of Setting Up a Specialised Financial Agency Supporting SME', in L. Csaba (ed.) The Hungarian SME Sector Development in Comparative Perspective, Budapest: CIPE - KOPINTDATORG.

Kiss, Y. (1994) 'Privatization paradoxes in East Central Europe', East European Politics and Societies 8(1): 122-152.

Kitschelt, H. (2000) 'Linkages between citizens and politicians in democratic polities', Comparative Political Studies 33(6/7): 845-879.

Koford, K. and Tschoegl, A.E. (1997) 'Problems of bank lending in bulgaria: information asymmetry and institutional learning', The Wharton School Working Paper.

Kopecky, P. (1995) 'Developing party organization in East-Central Europe: what type of party is likely to emerge?', Party Politics 1(4): 525-534.

Kornai, J. (1986) 'The soft budget constraint', Kyklos 39(1): 3-30.

Kroszner, R.S. (1998) 'The political economy of banking and financial regulatory reform in emerging markets', Research in Financial Services 10: 33-51.

Kubicek, P. (2004) Organized Labor in Postcommunist States: From Solidarity to Infirmity, Pittsburgh: University of Pittsburgh Press.

Levine, R. (2002) 'Bank-based or market-based financial Systems: which is better?', William Davidson Institute Working Paper No. 442.

Levitsky, S. and Way, L. (2002) 'The rise of competitive authoritarianism', Journal of Democracy 13(2): 51-65.

Lewis, P.G. (2001) 'The "Third Wave" of democracy in Eastern Europe. Comparative perspectives on party roles and political development', Party Politics 7(5): 543-565.

Li, Q. and Resnick, A. (2003) 'Reversal of fortunes: democratic institutions and foreign direct investment inflows to developing countries', International Organization 5(1): 175-211.

Lilov, A. (2004) Dialogut na Civilizaciite. Svetovnijat i bulgarskijat prehod, Sofia: Izdatelstvo Zaharii Stojanov.

Lipschitz, L., Lane, T. and Mourmouras, A. (2002) 'Capital flows to transition economies: master or servant?', IMF Working Paper No. 11.

Mair, P. and van Biezen, I. (2001) 'Party membership in twenty European democracies, 1980-2000', Party Politics 7(1): 5-21. 
Maliszewski, W. (2000) 'Central bank independence in transition economies', Economics of Transition 8(3): 749-789.

March, J. and Olsen, J. (1989) Rediscovering Institutions: The Organizational Basis of Politics, NY: The Free Press.

Maxfield, S. (1998) Gatekeepers of Growth: The International Political Economy of Central Banking in Developing Countries, Princeton: Princeton University Press.

Mayhew, A. (1998) Recreating Europe. The European Union's Policy towards Central and Eastern Europe, Cambridge: Cambridge University Press.

McDermott, G. (2004) 'The politics of institutional learning and creation: bank crises and supervision in East Central Europe', William Davidson Institute Working Paper No. 726.

Mihályi, P. (2000) 'FDI in Hungary. The post-communist privatization story re-considered', CEU Department of Economics Working Paper.

Mihályi, P. (2006) Personal interview, Budapest, Hungary, 6 April.

Miller, J. and Petranov, S. (2001) 'The financial system in the bulgarian economy', Bulgarian National Bank Discussion Paper.

Mörner, A. (1997) 'Banking law reform in Central and Eastern Europe - the influence of European Union banking legislation', The London Institute of International Banking, Finance and Development Law: Essays in International Financial and Economic Law No. 11.

Nenovsky, N., Peev, E. and Yalamov, T. (2003) 'Banks-Firms nexus under the currency board: empirical evidence from Bulgaria', Bulgarian National Bank Discussion Paper.

Nenovsky, N. and Rizopoulos, Y. (2003) 'Extreme monetary regime change: evidence from currency board introduction in Bulgaria', Journal of Economic Issues 37(4): 1-33.

Nord, R. (2000) 'Central and Eastern Europe and the new financial architecture', Finance and Development 37(3): 32-35.

Ortiz, G. (2003) 'Latin America: overcoming reform fatigue', Finance and Development 40(3): $14-17$.

Peev, D. (1998) 'MVF svali rozovite ochila na pravitelstvoto', Kapital, issue 22.

Pierson, P. (1997) 'Path dependency, increasing returns, and the study of politics', Harvard Center for European Studies Working Paper No. 7.

Przeworski, A. (1991) Democracy and the Market. Political and Economic Reform in Eastern Europe and Latin America, Cambridge: Cambridge University Press.

Rahn, R. and Utt, R. (eds.) (1990) Bulgarian Economic Growth and Transition Project (in Bulgarian: Proekt za ikonomicheski rastezh I prehod kym pazarna ikonomika v Bulgaria), Washington, DC: National Chamber Foundation.

Schimmelfennig, F. and Sedelmeier, U. (2004) 'Governance by conditionality: EU rule transfer to the candidate countries of Central and Eastern Europe', Journal of European Public Policy 11(4): 661-679.

Schmitter, P. (2001) 'The Influence of International Context Upon the Choice of National Institutions and Policies in Neo-Democracies', in L. Whitehead (ed.) The International Dimensions of Democratization: Europe and the Americas, Oxford: Oxford University Press.

Slantchev, B. (2005) 'The political economy of simultaneous transitions: an empirical test of two models', Political Research Quarterly 58(2): 279-294.

Soós, K.A. (2006) Personal interview, Budapest, Hungary, 10 April.

Spendzharova, A. (2003) 'Bringing Europe in? the impact of EU conditionality on Bulgarian and Romanian politics', Southeast European Politics 4(2-3): 141-156.

Stanchev, K. (2005) Personal interview, Sofia, Bulgaria, 2 December.

Stark, D. (1990) 'Privatization in Hungary: from plan to market or from plan to clan?', East European Politics and Societies 4(3): 351-392.

Thelen, K. (1999) 'Historical institutionalism in comparative politics', Annual Reviews of Political Science 2: 369-404. 
Todorova, G. and Raeva, O. (1997) 'Spasjavanijata na bankite dosega struvat na danukoplatcite nad \$4 milliarda', Kapital, issue 31.

Vachudova, M.A. (2001) 'The leverage of international institutions on democratizing states: Eastern Europe and the European Union', EUI-RSCAS Working Paper No. 33.

Vachudova, M.A. (2005) Europe Undivided: Democracy, Leverage, and Integration After Communism, Oxford: Oxford University Press.

Vachudova, M.A. and Snyder, T. (1997) 'Are transitions transitory? two types of political change in Eastern Europe Since 1989', East European Politics and Societies 11(1): 1-35.

Várhegyi, É. (2002) 'Hungary’s Banking Sector: Achievements and Challenges', EIB Articles No. 7. van Biezen, I. (2005) 'On the theory and practice of party formation and adaptation in new democracies', European Journal of Political Research 44: 147-174.

Walko, Z. (2004) 'The Bulgarian Financial Sector', Financial Stability Report 8 of Austrian National Bank.

Williamson, J. (ed.) (1994) The Political Economy of Policy Reform, Washington, DC: Institute for International Economics.

Williamson, J. (2003) 'From reform agenda to damaged brand name', Finance and Development 40(3): $10-30$.

Zaimov, M. and Hristov, K. (2003) 'Parichnata politika i ikonomikata: pette godini na balgarskija parichen savet', Bulgarian National Bank Discussion Paper.

Zielonka, J. and Pravda, A. (eds.) (2001) Democratic Consolidation in Eastern Europe, Oxford: Oxford University Press.

Zysman, J. (1983) Governments, Markets, and Growth, Ithaca: Cornell University Press.

\section{Appendix}

See Table A1.

Table A1 Prime ministers and government partisanship in Bulgaria and Hungary, 1989-2006

\begin{tabular}{lll}
\hline Bulgaria & & \\
\hline Prime minister & Government time in power & Governing party or coalition \\
\hline Andrey Karlov Lukanov & 3 Feb 1990-7 Dec 1990 & L: BSP \\
Dimitar Popov & 7 Dec 1990-8 Nov 1991 & non-partisan (backed by BSP) \\
Philip Dimitrov Dimitrov & 8 Nov 1991-30 Dec 1992 & R: SDS \\
Lyuben Borisov Berov & 30 Dec 1992-17 Oct 1994 & non-partisan (backed by BSP) \\
Reneta Ivanova Indzhova & 17 Oct 1994-25 Jan 1995 & interim \\
Zhan Vasilev Videnov & 25 Jan 1995-13 Feb 1997 & L: BSP \\
Stefan Antonov Sofiyanski & 13 Feb 1997-21 May 1997 & interim \\
Ivan Yordanov Kostov & 21 May 1997-24 Jul 2001 & R: ODS \\
Simeon Borisov Sakskoburggotski & 24 Jul 2001-16 Aug 2005 & R/C: NDSV + DPS \\
Sergey Dimitrievich Stanishev & 16 Aug 2005- & L/C: BSP + NDSV + DPS \\
\hline
\end{tabular}

BSP: Bulgarian Socialist Party (Balgarska Socialisticheska Partija); SDS: Union of Democratic Forces (Sajuz na Demokratichnite Sili); later ODS: United Democratic Forces (Obedineni Demokratichni Sili); DPS: Movement for Rights and Freedoms (Dvizhenie za Prava i Svobodi); NDSV: National Movement Simeon II (Nacionalno Dvizhenie Simeon Vtori).

$\mathrm{L}$ stands for left, $\mathrm{R}$ - for right, and $\mathrm{C}$ - for centrist. 
Table A1 (Continued)

Hungary

\begin{tabular}{lll}
\hline Prime minister & Government time in power & Governing party or coalition \\
\hline Miklós Németh & 23 Nov 1988-3 May 1990 & L: MSZP \\
József Antall & 3 May 1990-12 Dec 1993 & R: MDF + FKGP + KDNP \\
Péter Boross & 12 Dec 1993-15 Jul 1994 & R: MDF + FKGP + KDNP \\
Gyula Horn & 15 Jul 1994-6 Jul 1998 & L: MSZP + SZDSZ \\
Viktor Orbán & 6 Jul 1998-27 May 2002 & R: FIDESZ-MPP + FKGP + MDF \\
Péter Medgyessy & 27 May 2002-29 Sep 2004 & L: MSZP + SZDSZ \\
Ferenc Gyurcsány & 27 Aug 2004- & L: MSZP + SZDSZ \\
\hline
\end{tabular}

MSZP: Hungarian Socialist Party (Magyar Szocialista Párt); MDF: Hungarian Democratic Forum (Magyar Demokrata Fórum); FKGP: Independent Party of Smallholders, Agrarian Workers and Citizens (Független Kisgazda, Földmunkas és Polgári Párt); KDNP: Christian-Democratic People's Party (Kereszténydemokrata Néppárt); SZDSZ: Alliance of Free Democrats (Szabad Demokraták Szövetsége); FIDESZ-MPP: Alliance of Young Democrats (Fiatal Demokraták Szövetsége) Hungarian Civic Union (Magyar Polgári Párt) later FIDESZ-MPSZ (Magyar Polgári Szövetség).

$\mathrm{L}$ stands for left, $\mathrm{R}$ - for right, and $\mathrm{C}$ - for centrist. 